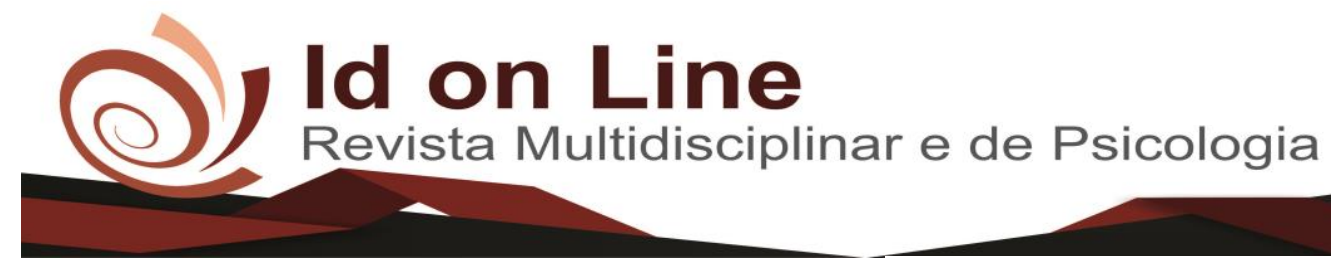

DOI: 10.14295/idonline.v13i46.1873

Artigo

\title{
Saúde e Qualidade de Vida no Trabalho (SQVT): Mudança da abordagem assistencialista para a preventiva em uma Agência da Previdência Social (APS) em Petrolina/PE
}

\author{
Débora Cavalcanti Bezerra da Silval ; Iracema Mayara Jambeiro Brandão Engelhardt ${ }^{2}$; \\ Alvany Maria dos Santos Santiago ${ }^{3}$; Luama Soraia Coelho Lins ${ }^{4}$
}

\begin{abstract}
Resumo: Em toda e qualquer organização é importante que haja harmonia entre os objetivos organizacionais e as expectativas e necessidades dos seus colaboradores Para que isso seja possível, faz-se necessário ampliar a consciência a respeito das condições de trabalho para propiciar melhor qualidade de vida no trabalho e que também gere melhores resultados para o consumidor final. Nesse âmbito, existem várias vertentes para tratar da qualidade de vida no ambiente organizacional. As duas abordagens assistencialista e a preventiva serão confrontadas neste estudo. Sendo que a primeira centra, principalmente, em agir nas consequências dos problemas surgidos pela baixa qualidade de vida no trabalho e a segunda, em agir nas causas. Dessa forma, o objetivo deste estudo é relatar o processo de mudança do enfoque assistencialista para o enfoque preventivo em Saúde e Qualidade de Vida no Trabalho na Agência da Previdência Social em Petrolina/PE. Realizou-se um diagnóstico organizacional, aplicando uma escala em dois momentos, visando identificar a satisfação no trabalho. A análise dos dados obtidos indicam uma maior satisfação e, por conseguinte, QVT dos servidores mais novos na organização.
\end{abstract}

Palavras chaves: Saúde no Trabalho. Qualidade de Vida no Trabalho. Mudança organizacional.

\section{Health and Quality of Work Life: \\ A change from the assistance to preventive approach at a Social Security Agency (APS) in Petrolina-PE, Brazil}

\begin{abstract}
It is important that there is harmony between the organizational objectives and the expectations and needs of its employees at every organization. To make this possible, it is necessary to raise awareness about working conditions to provide better quality of work life and it also produces better results for the final consumers. Within this framework, there are several approaches to address the quality of life within an organization. The assistence and preventive approaches were confronted in this study. The first focused mainly on acting on the consequences of the problems caused by the low quality of life at work and the second focused on acting on the causes. Thus, the objective of this study is to report the experience of the change, in Health and Quality of Work Life, from assistance to preventive approach at the Social Security Agency in Petrolina, state of Pernambuco, Brazil. An organizational diagnosis was made, applying a questionnaire in two moments, aiming to identify the work satisfaction. Data analysis indicates a higher satisfaction and, therefore, better work quality of life of younger employees in the organization.
\end{abstract}

Keywords: Work Health. Quality of Working Life. Organizational Change.

\footnotetext{
${ }^{1}$ Administradora e especialista em Ensino da Língua Inglesa pela Universidade Estácio de Sá. E-mail: deboracavalcantibs@ hotmail.com. Petrolina-PE, Brasil;

${ }^{2}$ Advogada, acadêmica em Psicologia na Univasf e Analista do Seguro Social do INSS - GEX Petrolina/PE.

E-mail: iracema.jambeiro@inss.gov.br. Petrolina-PE, Brasil;

${ }^{3}$ Doutora em Psicologia pela Universidade Federal do Espírito Santo. Professora do Programa de Pós-Graduação em

Dinâmica de Desenvolvimento do Semiárido (PPGDiDeS) e da Universidade Federal do Vale do São Francisco (Univasf). E-mail:alvany.santiago@univasf.edu.br.Petrolina-PE, Brasil;

${ }^{4}$ Administradora, mestranda no Programa de Pós-Graduação em Dinâmica de Desenvolvimento do Semiárido (PPGDiDeS), Univasf. E-mail: ideiaempreendedora@gmail.com. Petrolina-PE, Brasil; 


\section{Introdução}

A importância da qualidade de vida encontra-se atrelada às relações travadas em todos os âmbitos da vida social. É preciso dispor de boa qualidade de vida quanto ao corpo, à mente e ao espírito, quanto às relações estabelecidas com o meio ambiente e com os demais seres humanos. Particularmente no que diz respeito ao mundo do trabalho, a ideia de qualidade de vida assume, nos dias de hoje, no mínimo, um papel de instrumento de gestão de pessoas amplamente difundido por parte de um conjunto crescente de empresas e autores da área, muitas das vezes com o foco da aplicação da ideia de Saúde e Qualidade de Vida no Trabalho (SQVT) como ferramenta de incremento de produtividade de quem trabalha.

São várias as abordagens acerca de SQVT, porém neste trabalho apenas duas serão confrontadas: a assistencialista e a preventiva. Segundo Ferreira (2011), a abordagem assistencialista é individualista, pois preocupa-se em mudar o indivíduo, e é a concepção mais utilizada na área de gestão de pessoas. Já a abordagem preventiva trata da ergonomia do trabalho para com os trabalhadores, pois atenta-se a adaptação do ambiente de trabalho com o perfil dos funcionários.

$\mathrm{O}$ enfoque assistencialista apresenta-se, principalmente, por estas características: ele ainda recebe muita influência do foco que centra o indivíduo como único responsável pela SQVT no ambiente de trabalho; e as práticas de SQVT nas empresas apropriam-se de um caráter de atividades assistencialistas, oferecendo aos colaboradores um rol de atividades antiestresse, como serviços em spa, clubes e ginástica laboral.

Por outro lado, o enfoque preventivo preconiza a construção de um ambiente organizacional que legitime e valorize a intersubjetividade, ou seja, a capacidade de um trabalhador se relacionar e levar em consideração os pontos de vista de todos os seus colegas de trabalho, baseado na premissa de que os trabalhadores devem ser os sujeitos do seu trabalho, que eles transitem de mera mão de obra para ter a obra em suas mãos (LEITE; FERREIRA; MENDES, 2010).

Este trabalho tem o intuito de relatar o processo de mudança do foco assistencialista para o foco preventivo em um plano estratégico para melhoria da SQVT realizado na Agência da Previdência Social (APS) em Petrolina/PE. Por muito tempo, o Instituto Nacional do Seguro Social (INSS) tentou resolver o problema de baixa qualidade de vida no trabalho com ações paliativas massagens, terapias do corpo e da mente, confraternizações, ginásticas laborais, dias de folga, atividades de lazer - que visualizavam atenuar as consequências na vida de cada trabalhador (baixa motivação, absenteísmo, estresse, depressão, dores musculares, etc.). Atualmente, entende-se que as medidas que eram tomadas podiam até amenizar as mazelas sofridas pelos servidores, mas não extinguiam as doenças e condições, que acabavam por voltar a atrapalhar seu desempenho funcional. Por isso, o objetivo atual é tentar conter ou, pelo menos, diminuir significativamente as ocorrências, 
investigando a origem da insalubridade do setor e, consequentemente, propondo ações que eliminem as causas dos problemas.

\section{A importância da Saúde e Qualidade de Vida no Trabalho (SQVT)}

Moller (1992), destaca que a qualidade deve ser concebida não apenas sob o fator técnico, que visa "a obtenção dos lucros", mas também de forma complementar sob o fator da qualidade humana. Para o autor, a qualidade humana está "além dos lucros", traduzindo-se em satisfazer expectativas e desejos emocionais, como lealdade, comprometimento, consistência, comportamento, credibilidade, atitudes, atenção.

Assim, é possível definir qualidade como "aquilo que os clientes percebem através do atendimento de suas expectativas". Com isso em mente, torna-se papel da organização tomar conhecimento das expectativas dos seus clientes internos e externos e direcionar suas ações para a melhoria do desempenho, a fim de que seja gerada uma percepção mais positiva por parte dos consumidores e também dos colaboradores.

A gestão pela qualidade de vida, nesse sentido, se propõe a agir com vistas ao aprimoramento responsável e consciente da organização, com intuito de garantir sua perenidade sadia. Exige que o fator humano venha em primeiro lugar, dado que cada organização será produto da cultura que é produzida por seus constituintes. Esses pontos nos remete ao pensamento do pai da Administração: "a empresa privada (ou qualquer outra entidade) possui um único recurso verdadeiro: as pessoas. Ela desempenha-se tornando produtivos seus recursos humanos" (DRUCKER,1998, p.34). Desta forma, incumbe-se a estimular o sentimento de alegria, de forma que o trabalho venha a ser desempenhado da maneira mais prazerosa e agradável possível. Por conseguinte, os stakeholders - funcionários, diretores executivos, membros do conselho de administração e do conselho fiscal, auditores externos, fornecedores, representantes comerciais, despachantes, distribuidores, governos municipal, estadual, federal e, a sociedade como um todo, adequam-se a este conjunto É necessário que sejam conferidas às pessoas situações nas quais elas possam suprir suas necessidades de autoestima e de autorrealização a fim de que atuem como componentes verdadeiramente eficientes quanto ao desenvolvimento das organizações nas quais estão inseridas. Uma gerência eficaz será aquela que se baseia em princípios de relações humanas com pressupostos beneficentes e benevolentes (MASLOW, 2000).

Da mesma forma, Noulin (2002 apud FERREIRA 2011), destaca a importância de propiciar aos colaboradores uma boa qualidade de vida no trabalho, que deve ser entendida sob a ótica da ergonomia da atividade. Para o autor, a ergonomia visa a contribuir na concepção ou na evolução das 
situações de trabalho para que o próprio trabalho possa ser executado com o máximo conforto, satisfação e eficácia.

Esta concepção de SQVT, busca, intencionalmente, um rompimento com o viés de caráter assistencialista cuja finalidade se converte em elementos compensadores do estresse e do desgaste, sendo pretensiosas por adotarem cunho remediador dos males do trabalho.

Portanto, é ideal que se assuma uma abordagem que procure atuar sobre as reais causas que ameaçam a existência da SQVT, em vez de intentar agir sobre efeitos negativos resultantes do labor diário. Ou seja, deve existir a intenção de realizar a adaptação das variáveis do ambiente, não de fazer o juízo do indivíduo como variável de ajuste. Esse entendimento se sincroniza com o principal pressuposto da Ergonomia da Atividade que diz que deve haver a adaptação do trabalho ao ser humano e não realizar ajustes do ser humano ao seu trabalho.

Outro problema recorrente em várias agências da Previdência Social é que os servidores não conseguem ver os setores como componentes de um sistema, sendo o bom ou mau funcionamento dele decorrente do quão eficaz se dá a interligação das várias áreas que compõem a instituição. Dessa forma, para que eles deem significado às suas funções e, consequentemente, saibam a importância que exercem para a organização é essencial tentar mostrar que o trabalho de cada servidor é constituinte de um fluxo que pertence ao grande sistema que é a Previdência Social.

Peter Senge (1990 apud FLEURY et al., 2002), em suas obras sobre aprendizagem organizacional, diz que aprender, explorar e experimentar são uma das grandes motivações do ser humano em sua vida. Porém, a maioria das organizações é mais orientada para controlar os indivíduos do que para oferecer-lhes condições de aprendizagem. Ademais, o recompensa mais pela obediência às regras organizacionais do que pela disposição a aprender. Senge (1990) destaca primordialmente o indivíduo, seu processo de autoconhecimento, de clarificação de objetivos e projetos sociais. Depois, esse foco passa para o grupo e, finalmente, através do raciocínio sistêmico, para organização, ou seja, o trabalhador entende que ele e seus colegas fazem parte de um grande sistema responsável pelo fluído funcionamento da instituição. Conhecendo os processos e sua função dentro da empresa, os funcionários terão consciência de sua importância dentro do sistema, dando significado às suas tarefas, atribuições e funções. O conhecimento é um recurso de grande importância que pode e deve ser gerenciado para melhorar o desempenho da empresa (FLEURY et al., 2002).

Aliado a isso, no que se refere a adaptação do ambiente de trabalho ao trabalhador, percebe-se que o foco da ergonomia da atividade é "a interação entre os indivíduos e um determinado contexto de trabalho" (FERREIRA, 2008). Assim, as vivências de bem-estar no trabalho devem ter prevalência e, para isso, a ergonomia da atividade preocupa-se com cinco aspectos organizacionais: condições de trabalho, relações socioprofissionais de trabalho, organização do trabalho, elo trabalho - vida social, reconhecimento e crescimento profissional.

645 Id on Line Rev. Mult. Psic. V.13, N. 46 p. 642-655, 2019 - ISSN 1981-1179 Edição eletrônica em http://idonline.emnuvens.com.br/id 
Ainda nesse panorama de entendimento das relações estabelecidas entre os indivíduos e seu ambiente de trabalho, McGregor apresenta duas teorias o comportamento do indivíduo - a Teoria X e a Teoria Y. A primeira, também chamada de Teoria da Mediocridade das Massas, aduz que existe um grupo de pessoas com aversão ao trabalho, compreendendo esse como um mal necessário para obtenção de dinheiro, além de ter a preferência por ser dirigido e buscar a estabilidade. Isso configura um ambiente organizacional marcado pela centralização de poder que abarca consigo a não delegação de atividades, a apreciação pelo distanciamento da equipe, além de outras práticas, que podem ser consideradas nocivas. Quanto ao indivíduo, na concepção da Teoria Y, McGregor declara a existência de outro grupo de pessoas que o trabalho configura-se como natural e proveitoso, como as atividades de lazer. Ainda nesse panorama, demonstra preferências por autodireção e autocontrole. Em seu ambiente, estará sujeito ao comando que propulsiona a harmonia e a sinergia dentro da equipe a qual pertence. Ou seja, uma boa Gestão pela Qualidade e com foco na Qualidade de Vida no Trabalho estará incorporada em ambientes na abordagem da Teoria Y, cujo planejamento deverá se efetivar de forma de participativa a fim de que todos sejam envolvidos, gerando o comprometimento de todos. (SIQUEIRA, 2016).

\section{Método}

A pesquisa-diagnóstico, segundo Roesch (2005), apresenta diversas possibilidades de manifestação, uma delas é a utilizada neste trabalho e visa ao diagnóstico do ambiente organizacional. Em algumas situações, ocorrem dificuldades pela confidencialidade dos dados empresariais, muitas vezes de cunho financeiro, porém, como o INSS é uma entidade pública que deve disponibilizar os dados empresariais que, por conta de legislação.

Para abordar a problemática de forma prática, foi feito um levantamento sobre o ambiente de trabalho dos servidores da Agência da Previdência Social (APS) em Petrolina/PE. Nesse contexto de intervenção profissional, captar, tratar e analisar as imagens mentais que os trabalhadores fazem a respeito de seus contextos de trabalho, foi um importante requisito para implantação de ações de mudança que visem a promoção do bem-estar laboral, a eficiência e a eficácia dos processos produtivos. A partir disso, foi aplicada a Escala de Avaliação do Contexto de Trabalho (EACT) por Mendes e Ferreira, apresentada no Quadro 1, com o objetivo de ser um instrumento psicométrico, usado para diagnosticar as condições, a organização e as relações socioprofissionais de trabalho sob o ponto de vista dos próprios funcionários.

A EACT é composta por fatores alicerçados em: 
Quadro 1: Escala de Avaliação do Contexto de Trabalho

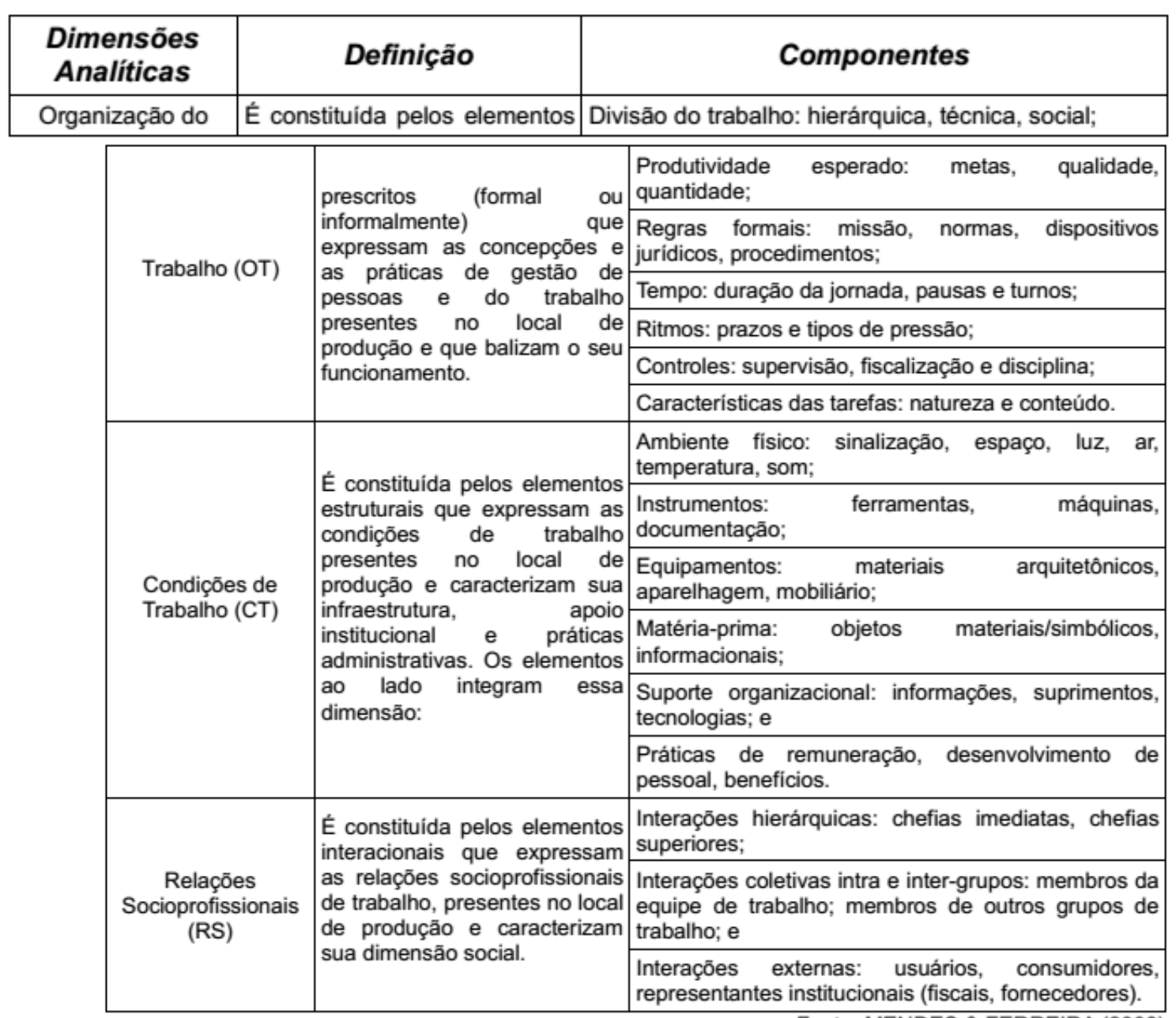

Fonte: MENDES \& FERREIRA (2008)

A escala tem a intenção de captar as representações que os trabalhadores têm de seu ambiente de trabalho, com base em três fatores analíticos interdependentes: (CT) condições do trabalho; (OT) organização do trabalho; e (RS) as relações socioprofissionais de trabalho. O Quadro 2 apresenta como a escala se organiza:

Quadro 2: Organização e definição dos fatores da EACT.

Fator "Condições de Trabalho - CT"

Definição: Expressa a qualidade do ambiente físico, posto de trabalho, equipamentos e material disponibilizado para a execução do trabalho. Ele é composto por 10 itens, com confiabilidade de 0,89 .

$\checkmark$ Fator "Organização do Trabalho - OT"

Definição: Expressa a divisão das tarefas, normas, controles e ritmos de trabalho. É composto por 11 itens, e tem confiabilidade de 0,72 .

$\checkmark$ Fator "Relações Socioprofissionais - RS"

Definição: Expressa os modos de gestão do trabalho, comunicação e interação profissional. Tem 10 itens, com confiabilidade de 0,87 .

Fonte: Mendes \& Ferreira (2008) 
A EACT é construída com itens negativos, ou seja, cada afirmação indica uma situação ruim. Em vista disso, a sua análise deve ser feita por fator, considerando o desvio padrão em relação ao ponto médio. Os resultados obtidos (média e desvio padrão) devem ser interpretados conforme os parâmetros apresentados na Figura 1:

Figura 1: Resultados obtidos

\begin{tabular}{|c|c|c|}
\hline Satisfatório & Crítico & Grave \\
\hline $\begin{array}{c}\text { Resultado } \\
\text { positivo e } \\
\text { produtor de } \\
\text { bem-estar no } \\
\text { trabalho. } \\
\text { Aspecto a ser } \\
\text { mantido e } \\
\text { consolidado no } \\
\text { ambiente } \\
\text { organizacional. }\end{array}$ & $\begin{array}{c}\text { Resultado mediano. } \\
\text { Indicador de "situaşào- } \\
\text { limite", potencializando o } \\
\text { mal-estar no trabalho e } \\
\text { risco de adoecimento. } \\
\text { Sinaliza estado de alerta, } \\
\text { requerendo providéncias } \\
\text { imediatas a curto e médio } \\
\text { prazo. }\end{array}$ & $\begin{array}{c}\text { Resultado negativo e } \\
\text { produtor de mal-estar } \\
\text { no trabalho. Forte risco } \\
\text { de adoecimento, } \\
\text { requerendo } \\
\text { providencias imediatas } \\
\text { nas causas visando } \\
\text { eliminá-las elou atemuá- } \\
\text { las. }\end{array}$ \\
\hline
\end{tabular}

Fonte: MENDES \& FERREIRA (2008)

\section{O ambiente de estudo : O INSS}

Ao Instituto Nacional do Seguro Social (INSS), autarquia do Governo Federal do Brasil, vinculada ao Ministério da Previdência Social, compete a operacionalização do reconhecimento dos direitos da clientela do Regime Geral de Previdência Social (RGPS) que atualmente abrange aproximadamente 65 milhões de contribuintes (Base de Dados da Previdência Social - 2011). O Regime Geral da Previdência Social tem caráter universalista e o INSS oferece à sociedade, tanto a certeza de renda futura àqueles que contribuem regularmente, seja através de seus empregadores, seja por iniciativa própria, quanto mantém benefícios temporários ou permanentes por incapacidade, acidente do trabalho, entre outros.

A Agência da Previdência da Previdência (APS) em Petrolina é a maior da Gerência Executiva Regional (GEXPTN) em demanda, sendo responsável pelo pagamento de cerca de um quarto dos benefícios da Gerência Executiva (44.972 de 187.304), e dos requerimentos de benefícios (1.100 de 3.977), encaminhando cerca de um quinto dos recursos administrativos de toda Gerência (44 de 222). 


\section{Resultados}

\section{Programa de Melhoria da SQVT - 2012:}

O INSS tem como missão: "Garantir proteção ao trabalhador e sua família, por meio de sistema público de política previdenciária solidária, inclusiva e sustentável, com o objetivo de promover o bem-estar social". E com essa vertente não poderia deixar de alongar o bem-estar social, também, para os seus servidores. Desta forma foi implantado o projeto de promoção da saúde e Qualidade de Vida no Trabalho. A Diretoria de Atendimento do INSS (DIRAT, 2008, p. 83) afirma que para a melhoria do atendimento ao público, várias ações foram feitas dentre elas o agendamento eletrônico programado, a ampliação do serviço de teleatendimento, e a gestão das vagas que são disponibilizadas pelas APS's. Segundo o projeto de SQVT (2012) estratégico da GEXPTN, para a DIRAT, a melhora da qualidade do atendimento deve englobar: humanização do atendimento, com eliminação de filas e alocação de servidores com perfil e preparo técnico adequado ao tipo de atendimento programado; redução do tempo de espera para atendimento (tempo decorrido entre a data de solicitação do agendamento e data de atendimento); redução do tempo de permanência do segurado na unidade de atendimento; redução do tempo de análise e conclusão dos processos de benefícios; redução do estoque de processos de benefícios pendentes de análise; reformulação do modelo de atendimento à população, com a ampliação e maior facilidade de acesso aos serviços previdenciários.

Percebe-se então que o objetivo é melhorar o serviço oferecido ao cidadão, de forma que seus direitos sejam garantidos. Como já foi visto, no mapa estratégico da organização, um dos pilares da gestão do INSS são os Resultados para a Sociedade e o Aprendizado e Crescimento internos. Fica claro que o direcionador de Gestão Estratégica de Pessoas assume o papel de sustentação para a efetivação dos resultados organizacionais e para o cumprimento da Missão do Órgão. Portanto, devese cuidar bem não só dos segurados, mas também dos funcionários.

O projeto de promoção da saúde e Qualidade de Vida no Trabalho surge, então, para legitimar um dos princípios que existe no mapa estratégico e apresentar melhorias nestes dois aspectos - saúde e QVT- no Instituto, já que o programa atual não estava apresentando resultados a longo prazo, buscando sempre o aperfeiçoamento do serviço.

O objetivo desse projeto, que aborda a questão de forma abrangente, afigura-se com:

Traçar um Plano de Gestão para a Agência da Previdência Social do INSS em Petrolina, de forma democrática e participativa, visando auxiliar no gerenciamento dos processos de trabalho e da equipe, no intuito de se obter melhoria de desempenho e a excelência do atendimento ao cidadão. 
Especificamente buscava construir ações de melhoria da gestão na APS Petrolina-PE, tornando-a mais eficaz e eficiente; Realizar um estudo das razões pelas quais a APS Petrolina-PE apresenta pontos de fragilidade em relação aos índices propostos no plano de ação anual; facilitar a construção de uma gestão participativa, uma vez que se trata de um dos princípios do INSS, sendo imprescindível a participação de todos para se obter melhores resultados; traçar estratégias de gestão, visando uma otimização dos recursos humanos; otimizar o uso das ferramentas gerências da APS, assim como melhorar a administração da agenda local buscando diminuir o tempo médio de espera pelo atendimento; fomentar o envolvimento de todos os servidores da APS Petrolina-PE no Plano de Gestão; reduzir o quantitativo de afastamentos do trabalho por parte dos servidores; desenvolver ações para melhoria da saúde e qualidade de vida no trabalho.

Dessa forma, a partir de 2012, as ações previstas no projeto - divididas em três fases - foram sendo realizadas dentro da Agência da Previdência Social em Petrolina. A primeira fase, se constituiu na confecção de um diagnóstico institucional, que contou com a participação de todos os servidores, foi utilizada para isso a metodologia ativo-participativa e ativo-dirigida, valendo-se das técnicas de exposição dialogada, trabalhos e dinâmicas em grupos. Aplicou-se então, a matriz SWOT, que é uma ferramenta utilizada para o estudo dos cenários internos e externos, com o levantamento das Forças (Strengths), Fraquezas (Weaknesses), Oportunidades (Opportunities) e Ameaças (Threats). O objetivo foi pontuar a situação da empresa em relação as essas variáveis e traçar metas com vistas a criar ou incrementar sua Gestão Estratégica (ver Quadro 3).

Quadro 3 - Resultado da matriz SWOT foi realizado antes colocar no problema

\begin{tabular}{|c|c|}
\hline $\begin{array}{ll}\text { - } & \text { Forças } \\
\text { - } & \text { Conhecimento; } \\
\text { - } & \text { Boa vontade; } \\
\text { - } & \text { Gerente da APS “novo"; } \\
\text { - } & \text { Responsabilidade; } \\
\text { - } & \text { Determinação; } \\
\text { - } & \text { Disposição; } \\
\text { - } & \text { Dinamismo; } \\
\text { - } & \text { Capacidade de liderança com dificuldade. }\end{array}$ & $\begin{array}{ll}\text { - } & \text { Fraquezas } \\
\text { - } & \text { Falta do conhecimento técnico; } \\
\text { - } & \text { Medo de cometer erros e ter que responder } \\
& \text { administrativamente; } \\
\text { - } & \text { A não otimização do tempo do servidor, com } \\
& \text { vistas a atualização sobre a legislação; } \\
\text { - } & \text { Pouca interação entre os colegas; } \\
\text { - } & \text { Falta de estímulo pessoal para assumir } \\
& \text { responSabilidades de chefias. } \\
\end{array}$ \\
\hline 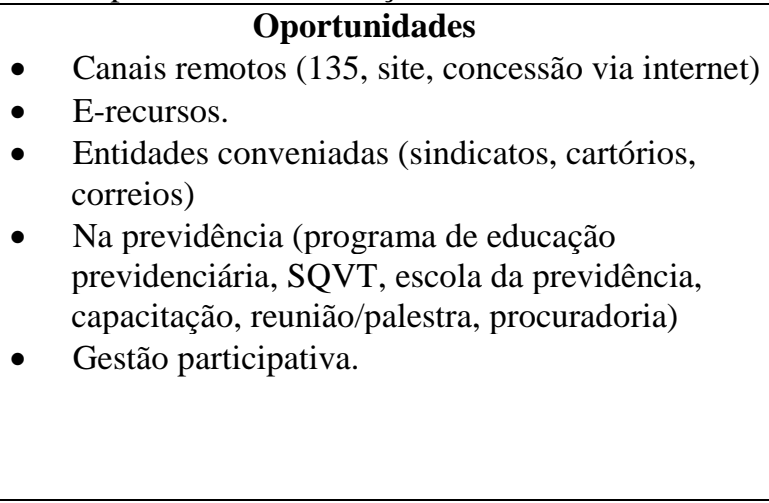 & \begin{tabular}{ll}
\multicolumn{1}{c}{ Ameaças } \\
- & Sistemas instáveis; \\
- & Espaço físico da APS inadequado; \\
mobística (material de consumo insuficiente, \\
mobiliário inadequado, aparelhos de apoio - \\
xerox, impressoras - danificados) \\
- Informações incompletas da mídia, gerando \\
demanda imediata. \\
- Metas mal dimensionadas, elaboradas com base \\
em números fictícios; \\
Elevado número de afastamento de servidores, \\
provocando a quebra do planejamento realizado;
\end{tabular} \\
\hline
\end{tabular}

650 Id on Line Rev. Mult. Psic. V.13, N. 46 p. 642-655, 2019 - ISSN 1981-1179 Edição eletrônica em http://idonline.emnuvens.com.br/id 


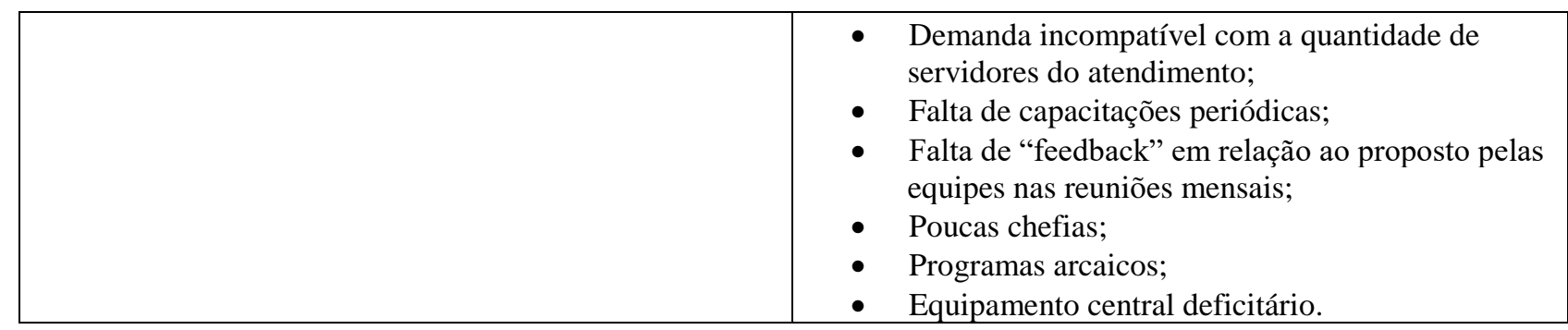

Fonte: Elaborado pelas autoras, com base nos dados do diagnóstico

Segundo o relatório da primeira fase do projeto de Promoção de Saúde e qualidade de vida no trabalho:

A partir daí é possível perceber, em primeira análise, o grande número de ameaças identificadas pelos servidores. Isso pode se traduzir em sentimentos de insegurança e medo que, em determinado grau, se tornam fraquezas. No quadrante das forças foram catalogadas as competências mais fortes, de acordo com os servidores da APS Petrolina, como disposição, boa vontade e dinamismo. No entanto, a partir do estudo do campo das fraquezas, em um comparativo com as forças, se estabelece uma relação um tanto contraditória, visto que agora esses elencam medo de cometer erros e ter que responder administrativamente, falta de estímulo pessoal para assumir responsabilidades de chefia e pouca integração entre os colegas, o que sugere mais uma vez um clima organizacional arraigado por insegurança e negativismo. Entretanto, os servidores manifestaram aspectos positivos como determinação e responsabilidade, além de indicarem a introdução de um novo gerente da APS como um fator otimista.

No estudo dos quadrantes de Oportunidades e Ameaças, é notório o reconhecimento dos canais facilitadores que podem vir a se tornar forças, como as tecnologias, associações, capacitações, apoios e remodulação da gestão, partindo para um padrão mais participativo. Contudo, foram eleitos como ameaças as próprias falhas a que essas tecnologias estão sujeitas. Além da sugestão de que há uma má distribuição de trabalho, de recursos materiais, o mau aproveitamento do espaço físico da APS, a existência de um planejamento errôneo, que torna deficiente o sistema de trabalho e que por sua vez gera demandas incompatíveis e ilusórias, produzindo um ciclo falho e limitador.

A análise SWOT se completa com um diagnóstico em saúde e qualidade de vida realizado através da metodologia de círculo de cultura, onde analistas com formação em psicologia, traçaram um perfil local através de vivências grupais intencionais e direcionadas. O que se pôde constatar, segundo o Anexo II do relatório:

1. Ambiente físico / equipamentos / sistemas: o grupo foi unânime em ressaltar a estrutura física da Agência como um dificultador do trabalho, além da falta de limpeza na Agência; ausência de condições de acessibilidade; layout inadequado para o funcionamento da Agência; foi pontuado algumas vezes também a dificuldade de se trabalhar com sistemas que não funcionam, muitas vezes, e que o servidor é quem precisa se adequar aos mesmos. 
2. Funções técnicas: teve bastante ênfase o distanciamento das áreas ditas técnicas da APS dos demais serviços que funcionam na Agência, a exemplo da perícia médica, serviço social e MOB. Essas áreas se ressentem de não participarem da rotina de trabalho de forma mais integrada, permeando um sentimento de isolamento, distanciamento e falta de motivação entre os servidores dessas áreas; em última instância há a existência de conflitos entre colegas em decorrência dessa ausência de integração entre os processos de trabalho na APS.

3. Relacionamento com a GEX: essa categoria foi bem contemplada nas falas dos participantes, afirmando que apesar da proximidade com a GEX facilitar em alguns aspectos, a interferência da GEX em muitas das decisões e processos de trabalho, dificulta a autonomia da Agência na condução do trabalho. $\mathrm{O}$ segundo ponto importante incluído nessa categoria diz respeito a imagem que os servidores da APS Petrolina tem de quem trabalha na Gerência Executiva, sendo esta vista como a parte privilegiada da Instituição em detrimento daquela, que repercute também no relacionamento que a APS estabelece com a GEX, o que pode impactar na fluidez do trabalho já que uma depende da outra constantemente.

4. Imagem externa / auto imagem: foi pontuada em algumas falas e citada em alguns questionários. A "imagem" de ser uma APS ruim, com índices ruins, conflitos nos relacionamentos interpessoais existe e ultrapassa os "muros" da Agência e é sentida mais fortemente por alguns, quando por exemplo participam de reuniões fora da APS. Essa imagem externa de cunho negativo afeta a imagem que os servidores tem do seu local de trabalho e em última instância a auto imagem de cada um deles. Ou seja, a forma como a Agência é vista externamente interfere na imagem que os servidores constroem deles mesmos.

5. Organização do Trabalho: Expressa as variáveis de tempo (prazo, pausa), controle (fiscalização, pressão, cobrança), características das tarefas (ritmo, repetição), sobrecarga e prescrição (normas) que influenciam a atividade de trabalho. Foi citado por vários servidores dados que remontam a um processo de trabalho que falta organização, a citar: falta de tempo para concluir os processos a contento, falta de interligação de um processo de trabalho com outros, ausência de planejamento, metas intangíveis (os índices não condizem mais com a realidade atual da APS), ausência de definição de papéis no atendimento, alta carga de trabalho para uns em detrimento de outros.

6. Reconhecimento e valorização: esse dado foi colocado por quase todos os grupos e percebemos certo ressentimento quando os servidores pontuam que não se sentem reconhecidos e valorizados pela Instituição, não recebem elogios pelo esforço diário em desempenhar suas atividades de trabalho. Alguns colocaram que o reconhecimento vem por parte do cidadão usuários que eles atendem todos os dias, fato que os deixa bastante satisfeitos e com um sentimento de orgulho de trabalhar no INSS.

7. Vivências passadas: os servidores, ao falarem de sua percepção na APS Petrolina, referiam-se constantemente a momentos anteriores, reportando-se a gestões passadas da Agência. Tais relatos, em sua maioria, eram carregados de carga emotiva negativa muito forte; sentimento de não ser ouvido, de se sentirem, muitas vezes, pressionados; com medo de expor suas opiniões, o que interfere na forma como eles percebem a Agência hoje.

8. Relacionamento interpessoal: essa categoria diz respeito as relações entre pares e foi colocado a ausência de sentimento de equipe na APS; alguns colocaram que, no aspecto individual, as pessoas eram de fácil relacionamento, mas não existia uma 
coesão no grupo como um todo, o que interferia no envolvimento e na participação nas atividades de rotina da Agência.

9. Sentimentos / sensações / impressões: sentimentos como frustração, impotência, desmotivação, solidão por todos os aspectos acima elencados; incapacidade diante dos problemas estruturais da APS. Em contrapartida, foi quase unânime o sentimento de esperança de que, com a mudança de gestão, a APS melhoraria realmente.

Na segunda fase do projeto, houve a construção de um diagrama de Ishikawa, ou espinha de peixe, que por meio de um brainstorming, mediado pela equipe de SQVT da GEXPTN, foi elaborado pelos servidores. A Figura 2 apresenta o resultado:

Figura 2: Produto da segunda fase do projeto - Diagrama de Ishikawa

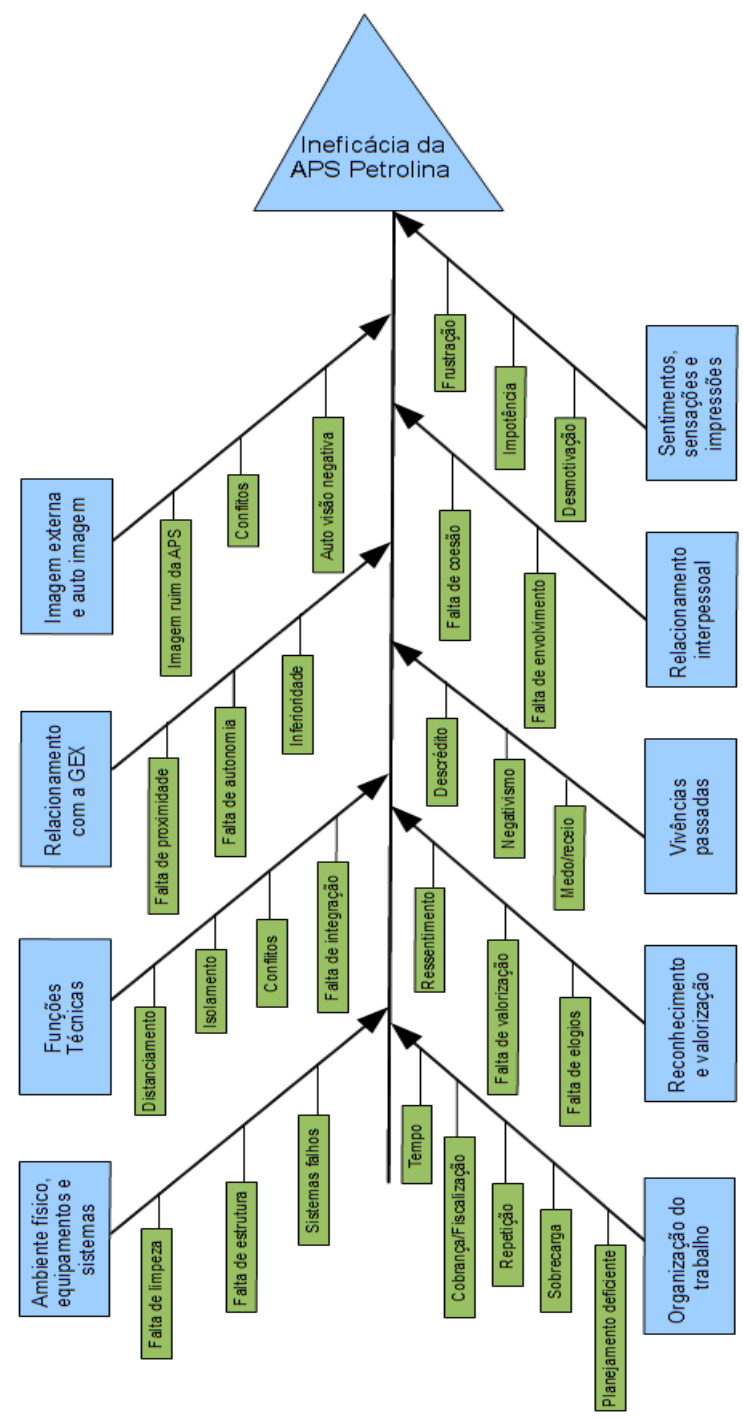

Fonte: Relatório da Segunda Fase (2013) 
Na sequência da aplicação do Diagrama de Ishikawa, foi aplicada a abordagem 5W2H para montar o plano de ação para gerenciar os problemas encontrados. A Tabela 2 apresenta os dados organizados em: What? ou O quê? as etapas da ação; Who? ou Quem? as pessoas responsáveis; Why? ou Por quê? a justificativa da ação; When? ou Quando? o tempo para realização da ação; How? ou Como? o método a ser utilizado; e How much? ou Quanto custa? que apresenta o custo as despesas das ações.

Tabela 2: 5W2H construídas na APS-Petrolina/PE

\begin{tabular}{|c|c|c|c|c|c|c|}
\hline $\begin{array}{l}\text { What } \\
\text { O quê? }\end{array}$ & $\begin{array}{l}\text { Who } \\
\text { Quem? }\end{array}$ & $\begin{array}{l}\text { Where } \\
\text { Onde? }\end{array}$ & $\begin{array}{c}\text { Why } \\
\text { Por quê? }\end{array}$ & $\begin{array}{c}\text { When } \\
\text { Quando? }\end{array}$ & $\begin{array}{l}\text { How } \\
\text { Como? }\end{array}$ & $\begin{array}{c}\text { How Much } \\
\text { Quanto custa? }\end{array}$ \\
\hline $\begin{array}{c}\text { Fiscalização, } \\
\text { supervisão e } \\
\text { manutenção da } \\
\text { limpeza }\end{array}$ & $\begin{array}{l}\text { Equipe de } \\
\text { acompanhamento } \\
\text { formada por } \\
\text { servidores }\end{array}$ & APS Petrolina & $\begin{array}{l}\text { Tornar ambiente } \\
\text { de trabalho mais } \\
\text { agradável e } \\
\text { adequado }\end{array}$ & $\begin{array}{l}\text { Durante todo o } \\
\text { ano }\end{array}$ & $\begin{array}{l}\text { Negociando } \\
\text { reparos, } \\
\text { discutindo } \\
\text { reorganização } \\
\text { do espaço, } \\
\text { realizando } \\
\text { alterações } \\
\text { necessárias }\end{array}$ & $\begin{array}{l}\text { A serem } \\
\text { definidos }\end{array}$ \\
\hline $\begin{array}{l}\text { Integração das } \\
\text { funções técnicas }\end{array}$ & $\begin{array}{l}\text { Toda a equipe de } \\
\text { servidores da } \\
\text { APS Petrolina } \\
\text { com apoio do } \\
\text { CFAI/SQVT }\end{array}$ & APS Petrolina & $\begin{array}{c}\text { Criação de } \\
\text { visão sistêmica, } \\
\text { interdependente } \\
\text { e integrada para } \\
\text { atingir melhores } \\
\text { resultados }\end{array}$ & $\begin{array}{l}\text { Durante todo o } \\
\text { ano }\end{array}$ & $\begin{array}{l}\text { Estabelecimento } \\
\text { de espaço para } \\
\text { reuniões; } \\
\text { Criação de } \\
\text { funcionograma }\end{array}$ & $\begin{array}{l}\text { A serem } \\
\text { definidos }\end{array}$ \\
\hline $\begin{array}{l}\text { Aproximação do } \\
\text { Gestor com os } \\
\text { colegas }\end{array}$ & $\begin{array}{l}\text { Toda a equipe de } \\
\text { servidores da } \\
\text { APS Petrolina } \\
\text { com apoio do } \\
\text { CFAI/SQVT }\end{array}$ & APS Petrolina & $\begin{array}{c}\text { Promover o } \\
\text { envolvimento da } \\
\text { equipe a fim de } \\
\text { fomentar } \\
\text { relações mais } \\
\text { proveitosas }\end{array}$ & $\begin{array}{l}\text { Durante todo o } \\
\text { ano }\end{array}$ & $\begin{array}{c}\text { Oficinas de } \\
\text { autoajuda, } \\
\text { gestão, gestão } \\
\text { de conflitos na } \\
\text { prática }\end{array}$ & $\begin{array}{l}\text { A serem } \\
\text { definidos }\end{array}$ \\
\hline $\begin{array}{c}\text { Minimização da } \\
\text { desmotivação, } \\
\text { apatia e frustrações }\end{array}$ & $\begin{array}{l}\text { Toda a equipe de } \\
\text { servidores da } \\
\text { APS Petrolina } \\
\text { com apoio do } \\
\text { CFAI/SQVT }\end{array}$ & APS Petrolina & $\begin{array}{l}\text { Estimulação de } \\
\text { proatividade e } \\
\text { satisfação } \\
\text { trazida através } \\
\text { do trabalho }\end{array}$ & $\begin{array}{l}\text { Durante todo o } \\
\text { ano }\end{array}$ & $\begin{array}{l}\text { Apresentação } \\
\text { constante de } \\
\text { feedback e } \\
\text { conscientização } \\
\text { a respeito da } \\
\text { importância do } \\
\text { trabalho de } \\
\text { cada um }\end{array}$ & $\begin{array}{l}\text { A serem } \\
\text { definidos }\end{array}$ \\
\hline
\end{tabular}




\begin{tabular}{|c|c|c|c|c|c|c|}
\hline $\begin{array}{l}\text { What } \\
\text { O quê? }\end{array}$ & $\begin{array}{c}\text { Who } \\
\text { Quem? }\end{array}$ & $\begin{array}{l}\text { Where } \\
\text { Onde? }\end{array}$ & $\begin{array}{l}\text { Why } \\
\text { Por quê? }\end{array}$ & $\begin{array}{c}\text { When } \\
\text { Quando? }\end{array}$ & $\begin{array}{l}\text { How } \\
\text { Como? }\end{array}$ & $\begin{array}{c}\text { How Much } \\
\text { Quanto custa? }\end{array}$ \\
\hline $\begin{array}{c}\text { Incentivo ao } \\
\text { sentimento de } \\
\text { reconhecimento e } \\
\text { mudança das } \\
\text { percepções } \\
\text { referentes à } \\
\text { vivências passadas }\end{array}$ & $\begin{array}{l}\text { Toda a equipe de } \\
\text { servidores da } \\
\text { APS Petrolina } \\
\text { com apoio do } \\
\text { CFAI/SQVT }\end{array}$ & APS Petrolina & $\begin{array}{c}\text { Falta de } \\
\text { reconhecimento } \\
\text { e crédito por } \\
\text { parte dos } \\
\text { servidores, } \\
\text { muitas vezes } \\
\text { acerca de seu } \\
\text { próprio potencial }\end{array}$ & $\begin{array}{l}\text { Durante todo o } \\
\text { ano }\end{array}$ & $\begin{array}{l}\text { Estabelecimento } \\
\text { de políticas de } \\
\text { valorização e } \\
\text { estimulo ao } \\
\text { dinamismo e } \\
\text { autonomia }\end{array}$ & $\begin{array}{l}\text { A serem } \\
\text { definidos }\end{array}$ \\
\hline $\begin{array}{l}\text { Promoção de } \\
\text { momentos de lazer, } \\
\text { informação e } \\
\text { recreação }\end{array}$ & $\begin{array}{l}\text { Toda a equipe de } \\
\text { servidores da } \\
\text { APS Petrolina } \\
\text { com apoio do } \\
\text { CFAI/SQVT }\end{array}$ & $\begin{array}{l}\text { APS Petrolina } \\
\text { e outros } \\
\text { espaços } \\
\text { cedidos para a } \\
\text { realização }\end{array}$ & $\begin{array}{c}\text { Vincular a } \\
\text { atividade e o } \\
\text { ambiente de } \\
\text { trabalho à } \\
\text { outras } \\
\text { atividades que } \\
\text { não somente } \\
\text { digam respeito } \\
\text { ao ambiente de } \\
\text { trabalho, } \\
\text { criando apreço } \\
\text { e proximidade } \\
\text { pela concepção } \\
\text { do seu trabalho } \\
\text { e colegas }\end{array}$ & $\begin{array}{l}\text { Durante todo o } \\
\text { ano }\end{array}$ & $\begin{array}{c}\text { Mini-cursos, } \\
\text { eventos e } \\
\text { oficinas } \\
\text { culturais, } \\
\text { palestras, } \\
\text { filmes, festas e } \\
\text { ações } \\
\text { educativas que } \\
\text { não estejam } \\
\text { ligadas ao } \\
\text { trabalho }\end{array}$ & $\begin{array}{l}\text { A serem } \\
\text { definidos }\end{array}$ \\
\hline $\begin{array}{c}\text { Integração e } \\
\text { aproximação com a } \\
\text { GEX }\end{array}$ & $\begin{array}{l}\text { Toda a equipe de } \\
\text { servidores da } \\
\text { GEX e APS } \\
\text { Petrolina, com } \\
\text { apoio do } \\
\text { CFAI/SQVT }\end{array}$ & $\begin{array}{l}\text { APS e GEX } \\
\text { Petrolina }\end{array}$ & $\begin{array}{c}\text { Estabelecer } \\
\text { proximidade e } \\
\text { sentimento de } \\
\text { pertencimento a } \\
\text { uma mesma } \\
\text { unidade }\end{array}$ & $\begin{array}{l}\text { Durante todo o } \\
\text { ano }\end{array}$ & $\begin{array}{l}\text { Reuniões e } \\
\text { eventos } \\
\text { integrados, } \\
\text { palestras e } \\
\text { ações de } \\
\text { endomarketing }\end{array}$ & $\begin{array}{l}\text { A serem } \\
\text { definidos }\end{array}$ \\
\hline
\end{tabular}

\begin{tabular}{|c|c|c|c|c|c|c|}
\hline $\begin{array}{l}\text { What } \\
\text { O quê? }\end{array}$ & $\begin{array}{c}\text { Who } \\
\text { Quem? }\end{array}$ & $\begin{array}{l}\text { Where } \\
\text { Onde? }\end{array}$ & $\begin{array}{l}\text { Why } \\
\text { Por quê? }\end{array}$ & $\begin{array}{c}\text { When } \\
\text { Quando? }\end{array}$ & $\begin{array}{c}\text { How } \\
\text { Como? }\end{array}$ & $\begin{array}{l}\text { How Much } \\
\text { Quanto } \\
\text { custa? }\end{array}$ \\
\hline $\begin{array}{c}\text { Melhoria da Imagem } \\
\text { interna e externa da } \\
\text { APS }\end{array}$ & $\begin{array}{l}\text { Toda a equipe de } \\
\text { servidores da } \\
\text { GEX e APS } \\
\text { Petrolina, com } \\
\text { apoio do } \\
\text { CFAI/SQVT }\end{array}$ & $\begin{array}{l}\text { GEX e APS } \\
\text { Petrolina e } \\
\text { toda a } \\
\text { comunidade }\end{array}$ & $\begin{array}{c}\text { Sentimento } \\
\text { negativista em } \\
\text { relação a APS e } \\
\text { quanto ao } \\
\text { potencial } \\
\text { pessoal dos } \\
\text { servidores }\end{array}$ & $\begin{array}{c}\text { Durante todo o } \\
\text { ano }\end{array}$ & $\begin{array}{l}\text { Manter melhorias } \\
\text { com vistas ao } \\
\text { atendimento de } \\
\text { excelência. } \\
\text { Promover a } \\
\text { divulgação dos } \\
\text { resultados da } \\
\text { APS para toda a } \\
\text { GEX, valorizando } \\
\text { o trabalho dos } \\
\text { servidores. Criar } \\
\text { ações de } \\
\text { marketing dentro } \\
\text { da APS para } \\
\text { divulgação dos } \\
\text { resultados aos } \\
\text { segurados. }\end{array}$ & $\begin{array}{l}\text { A serem } \\
\text { definidos }\end{array}$ \\
\hline $\begin{array}{c}\text { Melhoria na } \\
\text { Organização do } \\
\text { Trabalho }\end{array}$ & $\begin{array}{l}\text { Toda a equipe de } \\
\text { servidores da } \\
\text { APS Petrolina, } \\
\text { com apoio do } \\
\text { CFAI/SQVT }\end{array}$ & APS Petrolina & $\begin{array}{l}\text { Otimização do } \\
\text { tempo dos } \\
\text { servidores, } \\
\text { capacitá-los, } \\
\text { comprometê-los } \\
\text { e envolvê-los }\end{array}$ & $\begin{array}{c}\text { Durante todo o } \\
\text { ano }\end{array}$ & $\begin{array}{c}\text { Utilização de } \\
\text { planilha para } \\
\text { acompanhament } \\
\text { o dos processos, } \\
\text { criação de minis } \\
5 \mathrm{~W} 2 \mathrm{H} \text { para } \\
\text { execução de } \\
\text { atividades, } \\
\text { desenvolvimento } \\
\text { de laboratório } \\
\text { para capacitação }\end{array}$ & $\begin{array}{l}\text { A serem } \\
\text { definidos }\end{array}$ \\
\hline
\end{tabular}

Fonte: Relatório da Segunda Fase (2013)

A implantação desse plano de ação constituiu a terceira fase do projeto e foi desenvolvida nos meses seguintes ao da construção do diagnóstico.

Por fim, depois de oito meses de implementação do projeto: 
Para o Chefe do Serviço de Benefício da Gerência Petrolina, João Lima Júnior, a APS Petrolina é a maior da GEXPTN em demanda, sendo que no mês de novembro de 2012 foi responsável pelo pagamento de um quarto dos benefícios da GEX (44.972 de 187.304), obteve $27,65 \%$ dos requerimentos de benefícios (1.100 de 3.977) e encaminhou um quinto dos recursos administrativos de toda Gerência (44 de 222), sendo assim, entende-se que qualquer mudança de procedimentos é demorada e deve ser bem acompanhada para se consolidar.

Portanto, as alterações introduzidas na APS com a construção do Plano de Gestão demoram a ser percebidas nos indicadores, porém estão acontecendo mesmo antes da implementação propriamente dita.

Embora já se perceba uma melhoria nos indicadores, sabe-se da necessidade de uma melhora contínua, principalmente no aspecto da qualidade dos processos. Para tanto, pretende-se estabelecer rotinas organizacionais, realizar ações de capacitação e disseminação do conhecimento entre os colegas de trabalho.

Outro ponto de destaque no plano de gestão é atuação de forma mais presente junto aos sindicatos locais, de forma a auxiliar a produção inicial dos processos, dirimir dúvidas e controlar a emissão das declarações sindicais e também a quantidade de terras cedidas por proprietário, de forma semelhante ao que já tem sido realizado por outras Agências vinculadas à Gerência Executiva em Petrolina.

\section{Aplicação da Escala EACT Débora.}

A APS-Petrolina/PE é composta por 57 funcionários, desses apenas 21 responderam a escala EACT, com um percentual de $37 \%$ de respondentes. Trata-se de 13 homens e 8 mulheres, com idades entre 26 e 60 anos, sendo 18 técnicos do seguro social, 1 perito médico e 2 analistas do seguro social com formação em serviço social (ver Gráficos 1 e 2).
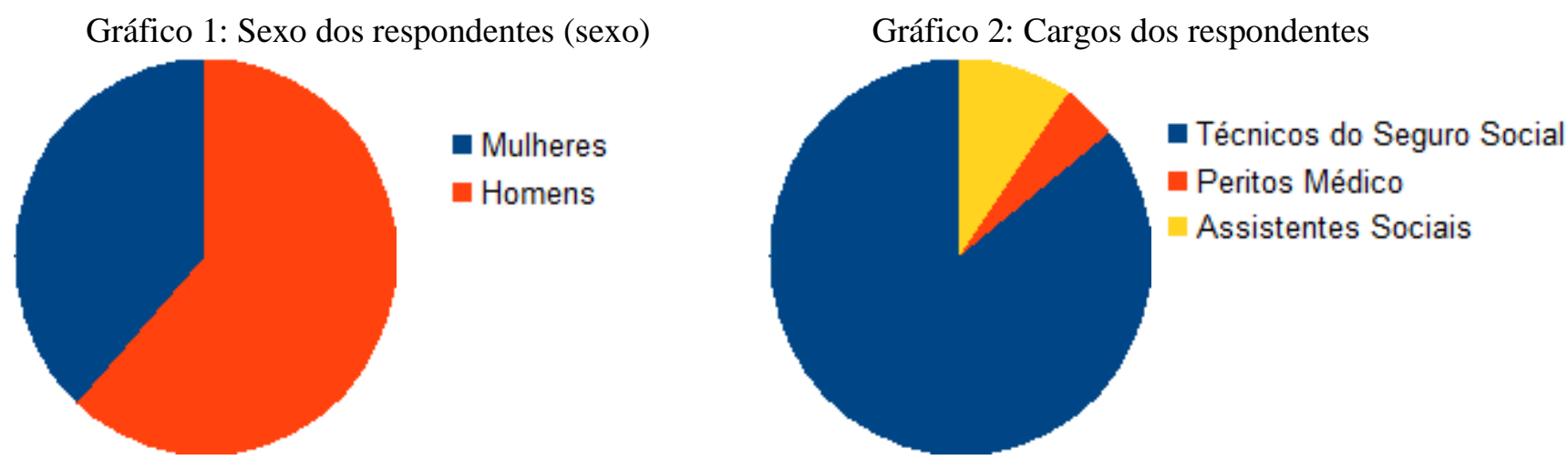

O Gráfico 3, a seguir, apresenta os dados coletados em relação aos aspectos do trabalho. 
Gráfico 3: Aspectos do trabalho, segundo percepção da APS-Petrolina/PE

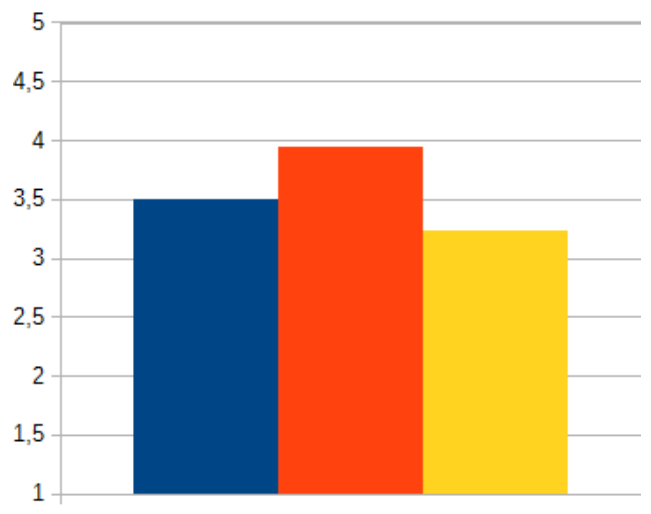

- Condições de Trabalho - Organização de Trabalho - Relações Socioprofissionais

O Quadro 4 apresenta o comparativo dos resultados com os parâmetros indicados por Ferreira \& Mendes, podemos observar que o contexto de trabalho, segundo os servidores da APS-Petrolina/PE, apresentaram:

Quadro 4: Resultados x Parâmetros Ferreira \& Mendes

\begin{tabular}{|c|c|c|c|}
\cline { 2 - 4 } \multicolumn{1}{c|}{} & Satisfatório & Crítico & Grave \\
\hline $\begin{array}{c}\text { Condições de Trabalho } \\
\text { (CT) }\end{array}$ & & 3,5 & \\
\hline $\begin{array}{c}\text { Organização de Trabalho } \\
\text { (OT) }\end{array}$ & & & 3,94 \\
\hline $\begin{array}{c}\text { Relações de } \\
\text { Socioprofissionais (RS) }\end{array}$ & & 3,23 & \\
\hline
\end{tabular}

Nenhum dos aspectos apresentou-se de forma satisfatória, CT e RS obtiveram resultados críticos, que segundo Ferreira \& Mendes, indicam uma situação-limite que pode potencializar o malestar e o risco de adoecimento, sinaliza um alerta para que medidas de curto e médio prazo sejam tomadas. A OT manifestou-se de forma grave, ou seja, esse aspecto é um produtor de mal-estar no trabalho, contendo forte risco de adoecimento e requer providências urgentes de forma a amenizar ou atenuar as situações.

O Gráfico 1 apresenta a comparação entre os servidores que estão a até 9 anos no INSS (lado esquerdo) com os que estão há mais de 9 anos (lado direito). Correlacionando alguns dados, percebeuse que quanto mais tempo de serviço, o respondente expressa-se menos satisfeito com o ambiente de trabalho, confirmado em todos os aspectos, CT, OT e RS. O item que teve diferença mais significante foi o de Relações Socioprofissionais, pois para os respondentes da coluna esquerda a qualificação da percepção se aproxima mais do nível satisfatório, ao ponto que a percepção dos da coluna direita fica quase se nivelando em grave. Além disso, a correlação realizada indicou também que a idade de todos 
os respondentes que estão a até 9 anos é menor do que as dos que estão há mais de 9 anos, uma média de 28,5 anos contra uma média de 49,13.

Gráfico 1: Tempo na instituição com a satisfação

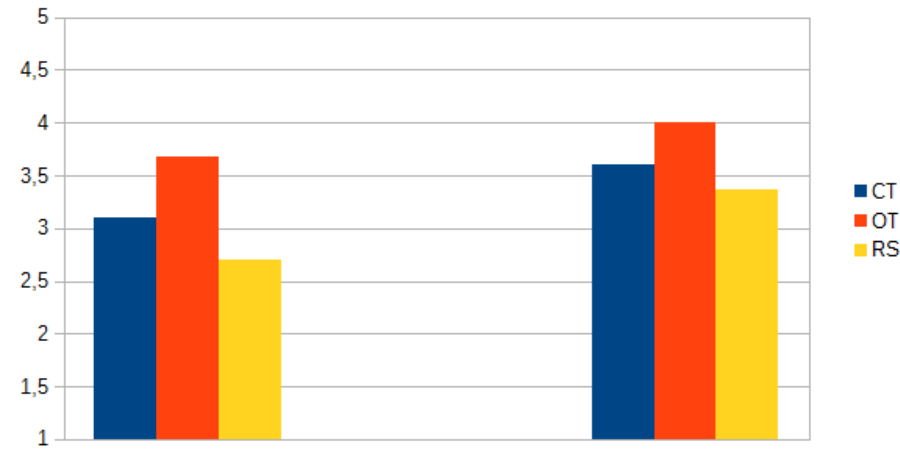

Fonte: Resultado da EACT

Em 2014 com este trabalho, para dar continuidade no projeto e averiguar se as ações ainda estavam surtindo efeito, urgiu a necessidade de se aplicar uma escala que avalia a percepção do contexto de trabalho com vistas a determinar a situação do ambiente de trabalho. Apesar dos resultados da escala não terem sido muito favoráveis, a situação se encontra em melhor estado do que estava antes da execução das ações do projeto de SQVT, pois quando são comparadas a análise de 2012 com os resultados colhidos com o questionário EACT, é possível verificar que o cenário é melhor percebido pelos servidores hoje em dia. Outro ponto que merece destaque, é o fato de que os indicadores de produtividade, a partir de 2012 até 2014, demonstram melhoras em relação ao ano anterior, como se pode verificar comparando os Índices de Resolutividade (IRES) de 2013 e de 2014. Esse índice indica o nível de resolução de processos dentro da APS, ou seja, é um indicador de eficácia e produtividade, pois mede a porcentagem de quantos atendimentos são resolvidos no mesmo dia em que o segurado dá entrada com suas demandas na agência. 
* Figuras 8 e 9: IRES 2013 x IRES 2014

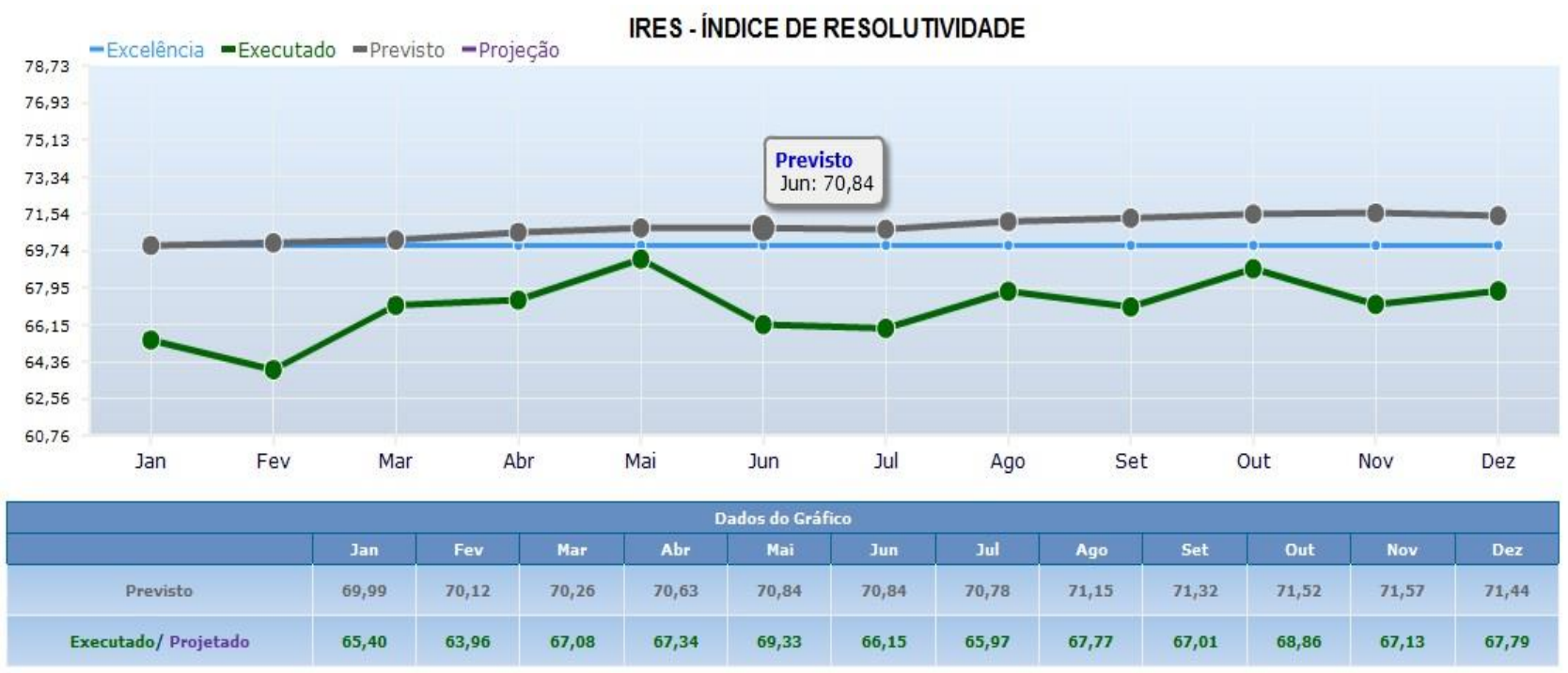

IRES 2013

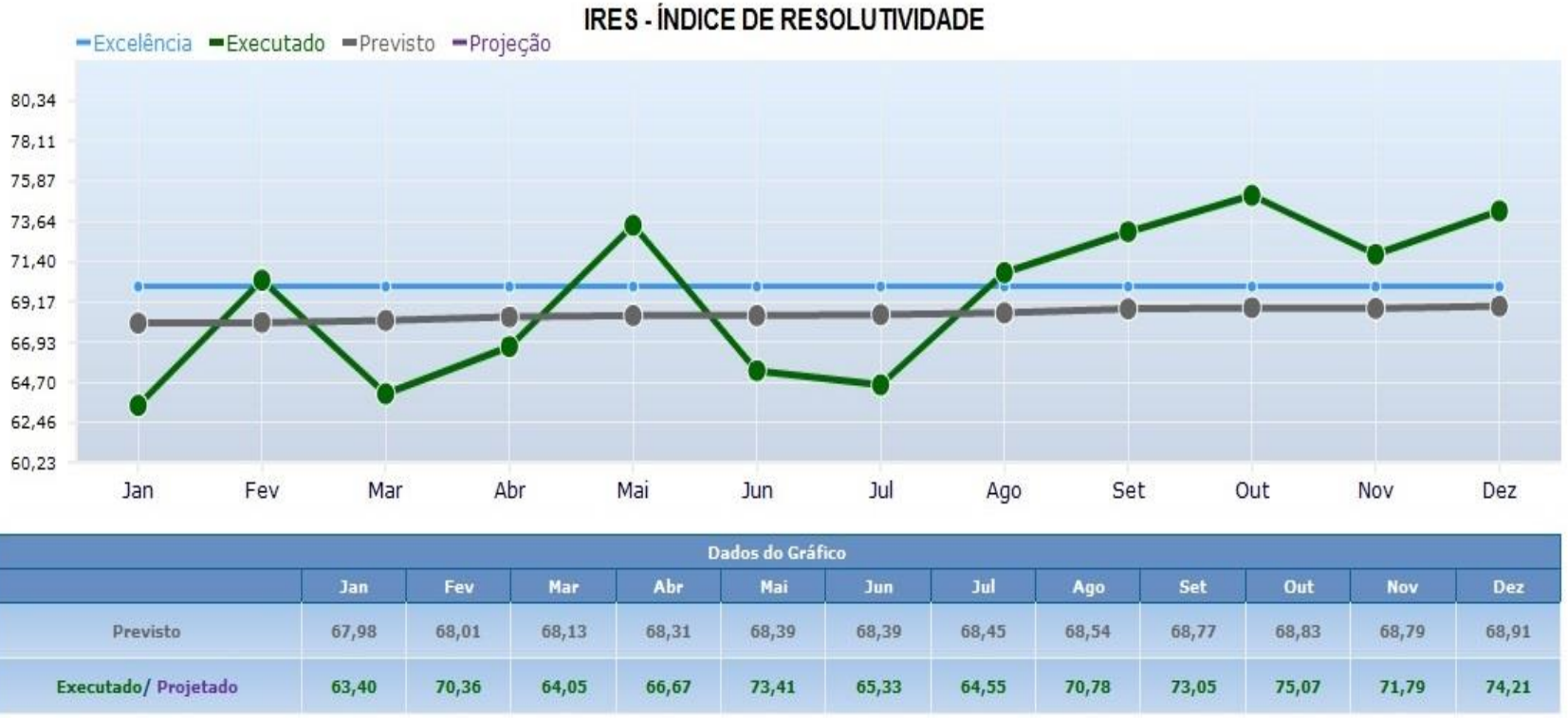

IRES 2014

A linha azul nas figuras indicam a porcentagem excelente para esse indicador, ou seja, quanto mais perto dessa linha ou acima dela melhor. O que é facilmente perceptível é que no ano de 2013, não teve nenhum mês que obteve porcentagem maior que 69,74 (linha azul), chegando um pouco perto no mês de maio quando atingiu 69,23 . No ano de 2014, salvo os meses de janeiro, março, abril, junho e 
julho, todos os outros meses exibiram índices de resolutividade maiores que o que a linha azul indicou. Cabe destacar que esta queda nos meses de janeiro, junho e julho já era prevista, por serem costumeiramente, meses em que há um grande número de afastamento de servidores por gozo de férias.

Pode-se dizer, portanto, que uma das razões da melhora do índice acima apresentado é resultado do trabalho da gestão estratégica de pessoas focada na saúde e qualidade de vida do empregado, com viés preventivo. O chefe do Serviço de Benefícios descreveu tais resultados:

O plano de gestão que foi implementado na APS Petrolina a partir de setembro de 2012 é bem abrangente, mas um dos principais eixos com certeza é a Saúde e Qualidade de Vida, isto porque desde o início se viu que melhorando este eixo haveria uma melhora em cadeia, pois a partir do momento em que os servidores se sentem com uma melhor qualidade de vida e existe menos adoecimento, eles podem prestar um melhor atendimento ao público externo, as equipes de trabalho funcionarão com mais sintonia e o trabalho dos gestores é facilitado. Para tanto se investiu, dentro das possibilidades orçamentárias disponíveis e da legislação pertinente aos servidores públicos, principalmente na melhoria física do ambiente de trabalho, na designação de gestores com identificação e habilidades para enfrentar os desafios propostos e na adequação da carga de trabalho. O plano vem sendo adequado às novas realidades e tem gerado bons resultados demonstrados através dos indicadores de desempenho da instituição onde alguns estabilizaram e outros melhoraram.

Apesar da produtividade em nível satisfatório, o contexto de trabalho ainda não é ideal segundo os próprios servidores, possuindo muito fatores a serem melhorados. A Seção Operacional de Gestão de Pessoas do INSS (SOGP) tem consciência disso e está empenhada em mudar ainda mais a situação da APS Petrolina/PE. O programa se mostra consistente dentro do INSS em Petrolina/PE, inclusive algumas das ações previstas para esse ano, segundo a psicóloga da SOGP apontam que:

A atual conjuntura impõe ao mundo do trabalho (seja este público ou privado) a tarefa de apreender e aplicar conhecimentos capazes de garantir que o trabalho se torne a um tempo efetivo e promotor de bem-estar individual e social. Neste sentido, percebe-se que o foco no desenvolvimento técnico dos trabalhadores não é suficiente para provocar o alcance dos resultados esperados pelas organizações, afinal conhecer nem sempre é saber, por aquele ter uma conotação voltada para o acumulo de informações, enquanto este é o conhecimento em ação.

Promover momentos que estimulem reflexão-ação-reflexão sobre modelos mentais, a "arte de aprender", convivencialidade e cultura de cooperação são bem-vindas, pois podem alavancar mudanças que afetem favoravelmente a motivação, o clima organizacional, o desenvolvimento dos servidores e por conseguinte contribua para o alcance da missão e visão institucional.

Assim o SQVT/CFAI - Setores de Saúde e Qualidade de Vida no Trabalho/Centro de Formação e Aperfeiçoamento do INSS - entende ser necessário avançar com os trabalhos iniciados na APS Petrolina, assim como expandi-lo para outras áreas de nossas Gerências. 
De acordo com o que foi constatado com a escala EACT, aqueles servidores mais antigos possuem uma percepção do contexto de trabalho menos positiva que as dos colaboradores mais novos, o que pode ser explicado pelo número maior de vivências negativas a que já estiveram expostos ao longo de sua carreira. A perspectiva da SQVT preventiva prioriza a mudança no ambiente de trabalho - organização, condições, recursos - fazendo com que os efeitos da otimização acarretem a satisfação do funcionário, o que invalida a tese de que as pessoas que devem ser mudadas e adaptadas ao labor. Dessa forma, o programa deve continuar trabalhando para que a percepção desses servidores que estão há mais tempo seja melhorada, pois a mudança para melhor no cenário do Instituto é recente se levarmos em consideração o tempo de existência do Órgão. A ineficácia que era atribuída à imagem da Instituição, tanto para os consumidores quanto para os servidores, é um fator que ainda perdura na mentalidade de muita gente, principalmente aqueles que tiveram experiência na empresa a partir da década de 90 do século XX.

Nessa conjuntura, Peter Senge (2013) afirma em seus ensinamentos sobre a quinta disciplina o pensamento sistêmico - que não existem culpados para os problemas de uma organização, ele diz que a tendência do ser humano é tentar culpar algo ou alguém pelos seus próprios erros - o concorrente, a imprensa, as mudanças do mercado, o governo. Todavia, o pensamento sistêmico, aquele que foca na importância de todos na interrelação de cada parte do grande sistema, nos desvela que não existe ninguém que possamos culpar por nossos problemas a não ser nós mesmos, pois fazemos parte - eu e meu problema - de um único sistema.

A falta de saúde no mundo atual é proporcional à incapacidade das pessoas de enxergar as situações, os processos, e até o mundo como um todo. O pensamento sistêmico possibilita ver interrelacionamentos em vez de eventos; ver os padrões de mudança em vez de "fotos instantâneas". Hoje, esse tipo de pensamento é mais necessário do que nunca para entendermos problemas como o aquecimento global, as mudanças climáticas, o tráfico internacional de drogas e outros colapsos mundiais. São contratempos que não possuem uma simples causa local. No âmbito das organizações acontece que, apesar dos inúmeros recursos de inteligência, tanto os materiais quanto os humanos, as empresas ainda entram em colapso, pois são "incapazes de reunir suas diversas funções e talentos para criar um todo produtivo". (SENGE, 2013)

Senge chama o pensamento sistêmico de quinta disciplina, pois ela é parte fundamental que se encontra implícita entre todas as outras quatro disciplinas - domínio pessoal, modelos mentais, visão compartilhada e aprendizagem em equipe. Todas elas envolvem uma mudança de mentalidade, passando de ver as partes para ver o todo, de considerar as pessoas como reativas e impotentes para mostrá-las como participantes ativas da sua realidade.

Implantar uma nova ideia numa organização que conta com funcionários que trabalham há 25 , 30 anos é uma tarefa complicada, pois os modelos mentais ou as imagens internas estão 
profundamente arraigadas sobre o funcionamento do mundo, fator que limita as pessoas de pensar e agir diferentemente. Os modelos mentais constroem nossa forma de agir, e cada indivíduo percebe determinado evento de forma diferente, ou seja, para muitos servidores o programa de SQVT pode ser visto como uma maneira de incrementar os resultados, porém alguns outros podem vê-lo como uma ameaça ou interferência negativa à forma que estão trabalhando e, consequentemente, não vão permitir que os benefícios sejam notados e incorporados ao ambiente de trabalho. (SENGE, 2013)

\section{Considerações finais}

As melhorias advindas de um programa de Saúde e Qualidade de Vida no Trabalho, dentro de uma organização, melhoram o ambiente de trabalho e o torna mais próximo de ser um lugar harmonioso e gerador de bem-estar. Dessa forma, quanto melhor estruturado e planejado o programa, por mais tempo perdurará e sustentará aquela empresa com eficiência e produtividade, pois o trabalhador se sentirá parte importante para os fins da organização. Adicionando a isso um viés preventivo, onde as potenciais causas de mal-estar no trabalho são analisadas e extintas, as doenças causadas pelo labor também serão menos incidentes.

O Instituto Nacional do Seguro Social conseguiu perceber a importância da instauração de uma cultura organizacional baseada nas pessoas, responsáveis pela elevação ou diminuição da imagem da Instituição, e, portanto, construiu um plano de ação para implementar um programa de SQVT. No primeiro momento, as propostas eram oferecer serviços terapêuticos: oficinas de saúde, consultas psicológicas, acompanhamento de nutricionista, ginásticas laborais, massagens, entre outros. A intenção era fazer com que os impactos da vida laboral fossem remediados ali, naquele momento. Porém, em um segundo momento, observou-se que aquelas medidas não acabariam com os problemas de saúde dos funcionários, pois as causas dos males não estavam sendo analisadas como sendo as impulsionadoras das doenças. A partir daí, a mentalidade acerca da prevenção e não da remediação começou a ser dada sua devida importância pelos gestores de pessoas.

É sabido que o caminho para o atendimento com excelência é árduo e contínuo, ainda mais se tratando de uma empresa pública, onde todas as ações devem ser permitidas pelo governo, por meio de legislação, o que limita a criatividade dos gestores responsáveis, pois a tomada de decisão vem, hierarquicamente, de cima para baixo e estando a APS no último nível do organograma, o processo de mudança se torna lento e não muito prático. Aliado a isso, ainda existe o fato de que a GEXPTN é pioneira nesse trabalho de cunho preventivo, fazendo com que a cúpula estratégica do INSS muitas vezes não autorize os planejamentos da Seção Operacional de Gestão de Pessoas em Petrolina/PE,

662 Id on Line Rev. Mult. Psic. V.13, N. 46 p. 642-655, 2019 - ISSN 1981-1179 Edição eletrônica em http://idonline.emnuvens.com.br/id 
pois desconhecem a abordagem, em SQVT, que deixa de considerar os efeitos para considerar as causas dos males ocupacionais.

Dentro do que for possível, os esforços devem ser programados para que o programa de SQVT seja incorporado, o máximo possível, ao INSS, com ferramentas que articulem a consciência pessoal e as habilidades de reflexão, estruturas que tentem institucionalizar a prática regular dos modelos mentais, criando uma cultura que promova questionamentos e desafios aos pensamentos existentes. Deve-se popularizar, entre os colaboradores, os objetivos ao qual o Instituto quer alcançar, ou seja, alinhar a equipe com um propósito comum a fim de que todos se engajem em tornar o serviço excelente na organização. Com o pensamento sistêmico, a visão compartilhada e a compreensão de como complementar os esforços dos outros, os servidores transformarão a causa do Instituto como uma extensão de suas visões pessoais.

Essa área que aborda a saúde e qualidade de vida no trabalho com uma abordagem preventiva é bastante nova e sua literatura ainda é escassa. É preciso que estudos complementares e relatos de experiência sejam feitos para que a teoria seja utilizada com mais firmeza e possa ser referência para as empresas, ao invés da ultrapassada vertente assistencialista de saúde e qualidade de vida no trabalho. A Universidade Federal do Vale do São Francisco tem papel decisivo nesse processo de aprofundamento, podendo desenvolver estudos e projetos de extensão junto a órgãos e empresas da região, em especial no INSS da GEXPTN, que vem avançando na aplicação e teoria desse viés.

\section{Referências}

ASSESSORIA DE COMUNICAÇÃO SOCIAL DA PREVIDÊNCIA (Org.). Base de Dados da Previdência Social. 2011. Disponível em: 〈http://www.previdencia.gov.br〉. Acesso em: $10 \mathrm{dez}$. 2014.

CURSO PARA DISSEMINADORES DO EXTERNOS DA PREVIDÊNCIA SOCIAL. Caderno do Educando Previdenciário. Petrolina: Previdência Social, 2014.

DRUCKER, P. F. Introdução à administração. 3. ed. São Paulo: Pioneira, 1998.

FERREIRA, M. C.; MENDES, A. M. (2004). Gestão de Pessoas Focada na Qualidade de Vida no Trabalho: Bem-Estar, uma Tarefa de Todos. Empresa X (Org.). Fórum Qualidade de Vida Trabalhando e Vivendo com Qualidade (pp. 1-7). Brasília: Empresa X.

FERREIRA, M. C. A ergonomia da atividade se interessa pela qualidade de vida no trabalho? Reflexões empíricas e teóricas. Caderno Psicologia Social no Trabalho, [online], p. 83-99, 2008. ISSN 1516-3717. 
A ergonomia da atividade pode promover a Qualidade de Vida no Trabalho? Reflexões de natureza metodológica. Revista Psicologia: Organizações e Trabalho, [online], p.8-20, 31 out. 2011. ISSN 1984-6657.

FLEURY, M. T. L. et al. As pessoas na organização. 7. ed. São Paulo: Gente, 2002.

GABINETE DO MINISTRO DA PREVIDÊNCIA SOCIAL (Org.). Informativo eletrônico da Previdência Social. 2009. Disponível em: <http://www.previdencia.gov.br>. Acesso em: 24 jan. 2015.

INSTITUTO BRASILEIRO DE GEOGRAFIA E ESTATÍSTICA (IBGE). Censo demográfico das cidades. Disponível em: <http://cidades.ibge.gov.br/xtras/uf.php?lang=\&coduf=26\&search= pernambuco $>$. Acesso em: 14 nov. 2014.

KAPLAN, R; NORTON, D. P. Organização orientada para a estratégia. Campus, 2000.

LEITE, J. V.; FERREIRA, M. C.; MENDES, A. M. Mudando a Gestão da Qualidade de Vida no Trabalho. Revista Psicologia: Organizações e Trabalho, [online], p.109-123, 22 mar. 2010. ISSN 1984-6657.

MASLOW, A. H. Maslow no gerenciamento. Rio de Janeiro: Qualitymark Ed., 2000.

MENDES, A. M.; FERREIRA, M. C. Contexto de Trabalho. In: SIQUEIRA, Mirlene M. M. (Org.). Medidas do comportamento organizacional: ferramentas de diagnóstico e gestão. Porto Alegre: Artmed, 2008.

MOLLER, C. O lado humano da qualidade: maximizando a qualidade de produtos através de desenvolvimento das pessoas. São Paulo: Pioneira, 1992.

OLIVEIRA, D. P. R. Planejamento estratégico: conceitos, metodologia e prática. 14 ed. São Paulo: Atlas, 1999.

SENGE, P. M. A quinta disciplina: arte e prática da organização que aprende. 29 ed. Rio de Janeiro: BestSeller, 2013.

Planalto. Decreto 7.556/2011. Disponível em: <https://www.planalto.gov.br/ccivil_03/_Ato20112014/2011/Decreto/D7556.htm\#art6>. Acesso em: 13 nov. 2014.

PREVIDÊNCIA. Missão do INSS. Disponível em: <http://www.previdencia.gov.br/aprevidencia/historico/misso/>. Acesso em: 01 nov. 2014.

PREVIDÊNCIA. Visão do INSS. Disponível em: <http://www.previdencia.gov.br/viso/>. Acesso em: 01 nov. 2014.

ROESCH, S. M. A. Projetos de estágio e de pesquisa em Administração: Guia para estágios, trabalhos de conclusão, dissertações e estudos de caso. São Paulo: Atlas, 2005.

SEÇÃO OPERACIONAL DE GESTÃo DE PESSOAS (Org.). Relatório da Primeira Fase. Petrolina: Previdência Social, 2012.

. Relatório da Segunda Fase. Petrolina: Previdência Social, 2013.

. Relatório da Terceira Fase. Petrolina: Previdência Social, 2013. 
SIQUEIRA, W. A Teoria $\mathbf{X}$ e a Teoria Y, de Douglas McGregor. Disponível em: $<$ http://www.administradores.com.br/artigos/cotidiano/a-teoria-x-e-a-teoria-y-de-douglasmcgregor/51506/>. Acesso em: 15 nov. 2014.

\section{Como citar este artigo (Formato ABNT):}

SILVA, Débora Cavalcanti Bezerra da; ENGELHARDT, Iracema Mayara Jambeiro Brandão; SANTIAGO, Alvany Maria dos Santos; LINS, Luama Soraia Coelho. Saúde e Qualidade de Vida no Trabalho (SQVT): Mudança da abordagem assistencialista para a preventiva em uma Agência da Previdência Social (APS) em Petrolina/PE . Id on Line Rev.Mult. Psic., 2019, vol.13, n.46, p. 642665. ISSN: 1981-1179.

Recebido: 06/06/2019;

Aceito: 15/07/2019. 